\title{
ПОВЫШЕНИЕ ЭФФЕКТИВНОСТИ ВОЗДЕЛЬВАНИЯ ЛЬНА-ДОЛГУНЦА В БИОЛОГИЗИРОВАННОЙ СИСТЕМЕ ЗЕМЛЕДЕЛИЯ
}

\section{INCREASING THE EFFICIENCY OF FLAX CULTIVATION IN A BIOLOGIZED FARMING SYSTEM}

G. Efremova

E. Zotova

Summary. The paper presents the results of research conducted in 2018-2019. In the Ivanovo state agricultural Academy (Ivanovo region, Ivanovo) on the study of environmentally safe methods for increasing the productivity of flax-Longhorn based on the use of sideral precursors and biological preparations. The purpose of scientific research was to study the effectiveness of new precursors-white mustard and peas with oats, biofungicides and bioinsecticide in the cultivation of flaxLonghorn varieties Tomsk-17. The research objectives were to determine the influence of sideral precursors and biological preparations on the productivity of flax and the economic efficiency of the elements of biologized technology.

Sideral crops and biological preparations had a positive impact on the formation of flax yield and the efficiency of its cultivation in biologized farming systems. The use of biologics against the background of sideral precursors allowed to increase the yield of straw and flax seeds and realize the potential of the Tomsk-17 variety in the conditions of the Ivanovo region at the level of $104.0 \mathrm{C} / \mathrm{ha}$ of straw and $15.5 \mathrm{C} / \mathrm{ha}$ of seeds.

The technology of growing flax in the crop rotation after sideral steam and the use of biological means to stimulate growth and protect plants is cost-effective.

Keywords: sideral precursors, biological preparations, fiber flax, yield.
Ефремова Галина Вячеславовна

К.с.-Х.н., дочент, Ивановская государственная сельскохозяйственная академия имени Д. К. Беляева efremova37@bk.ru

Зотова Елена Юрьевна

К.С.-Х.н., доцент, Ивановская государственная сельскохозяйственная академия имени Д. К. Беляева

Аннотация. В работе представлены результаты исследований, проведенных в 2018-2019 гг. В Ивановской государственной сельскохозяйственной академии (Ивановская область, г. Иваново) по изучению экологически безопасных приемов повышения продуктивности льна-долгунца на основе использования сидеральных предшественников и биологических препаратов. Целью научных исследований стало изучение эффективности новых предшественников — горчицы белой и гороха с овсом, биофунгицидов и биоинсектицида при выращивании льна-долгунца сорта Томский-17. В задачи исследований входило установить влияние сидеральных предшественников и биологических препаратов на продуктивность льна-долгунца и экономическую эффективность элементов биологизированной технологии.

Сидеральные культуры и биологические препараты оказывали положительное влияние на формирование урожайности льна-долгунца и эффективность его возделывания в биологизированных системах земледелия. Использование биопрепаратов на фоне сидеральных предшественников позволило повысить урожайность соломы и семян льна-долгунца и реализовать потенциал сорта Томский-17 в условиях Ивановской области на уровне 104,0 ц/га соломы и 15,5 ц/га семян.

Технология выращивания льна-долгунца в севообороте после сидерального пара и применения биологических средств стимулирования роста и защиты растений экономически эффективна.

Ключевые слова: сидеральные предшественники, биологические препараты, лен-долгунец, урожайность.

ние почвенного плодородия. Поэтому, необходим поиск альтернативных вариантов пополнения органического вещества в почве, одним из наиболее эффективных является использование сидератов [2, с. 42].

Создание высокого агрофона и размещение льна в севообороте с короткой ротацией способствует получению высокой и стабильной урожайности льнопродукции [3, с. 26-31]. Не менее важно повышение устойчивости сорта Томский-17 к фузариозу, во влажные годы степень поражения растений превышает порог вредо- 
носности и ведет к снижению продуктивности $[4$, с. 3435]. Изучение новых предшественников льна-долгунца, биологических препаратов направлено на реализацию потенциала продуктивности сортов, повышение устойчивости к патогенам, получение экологически чистой продукции, экономию затрат.

Изучение новых предшественников льна-долгунца, повышение устойчивости к неблагоприятным факторам на основе биологизированной технологии возделывания является весьма актуальной темой исследований, направленной на достижение потенциала продуктивности сортов.

\section{Цель и залачи исслеАований}

Цель исследований: изучение эффективности новых предшественников - горчицы белой и гороха с овсом, биофунгицидов и биоинсектицида при выращивании льна-долгунца сорта Томский-17.

Задачи исследований: установить влияние сидеральных предшественников и биологических препаратов на продуктивность льна-долгунца и экономическую эффективность элементов биологизированной технологии.

\section{Условия, объекты \\ и метолы исслеАований}

Период вегетации 2018 года можно охарактеризовать как достаточно теплый и слабо засушливый, что оказало благоприятное на рост, развитие и накопление вегетативной массы сидеральных культур. Период вегетации с июля 2019 года можно охарактеризовать как избыточно влажный и умеренно холодный, в начале вегетации наблюдалась засушливая и теплая погода, что способствовало развитию фузариоза льна-долгунца и льняной блошки, что создавало условия для установления эффективности биологических методов борьбы с болезнями и вредителями.

Научные исследования проводили путем постановки полевого опыта в НУЦ ФГБОУ ВО Ивановская ГСХА имени Д.К. Беляева, площадь опытной делянки - 40 м2, повторность четырехкратная, расположение делянок последовательное.

Посев сидератов проводили в 2018 году в 2 срока: 1 срок - в мае, 2 срок - в июле. Норма высева семян горчицы 20 кг/га, гороха в смешанном посеве - 200 кг/ га (2 млн. семян на 1 га), овса -35 кг/га (1,2 млн. семян на 1 га). Семена сидеральных культур перед посевом обрабатывали 2\% раствором стимулятора роста «Энерген Аква». Минеральные удобрения вносили перед предпосевной культивацией из расчета N12P40K40. Посев льна сорта Томский -17 проводили в 2019 году после сидеральных предшественников селекционной сеялкой ССНП-16 с междурядьями 10 см. Норма высева 23 млн. всхожих семян на 1 га. Для посева использовали кондиционные семена первой репродукции. В 2018 году и перед посевом льна в 2019 году изучали влияние сидератов на агрохимические и физические свойства почвы. В 2019 году проводились учеты элементов структуры урожая, урожайности соломы и семян в соответствии с методикой проведения полевых опытов со льном-долгунцом. В работе использована методика агрохимических исследований [5, с. 394-401].

В научном опыте изучались сидеральные предшественники: горох-овес, горчица белая; биологические препараты: Витариз получен на основе Pseudomonas fluorescens, Трихозан - в состав препарата входит гриб рода триходерма Trichoderma Lignorum, Биоинсектицид содержит комбинацию природных авермектинов, которые продуцируются непатогенными почвенными грибами Bacillus thuringiensis, Streptomyces sp., Beauveria bassiana. Трихозан - 3 л/га вносили осенью, после уборки предшественника и весной, под предпосевную культивацию в дозе 2 л/га. Трихозан - 1 л/т и Витариз -1 л/т применяли для последовательного протравливания семян перед посевом. Витариз - 1л/га использовали для двукратной обработки растений в период вегетации, Биоинсектицид - 3 л/га - для однократной обработки в начале вегетации. Для повышения биологической активности препаратов в рабочую жидкость добавляли гумат Плодородие Универсал в дозе 300 мл/га.

\section{Результаты исслеАований и их обсужАение}

По данным таблицы 1 можно сделать вывод, что урожайность горчицы белой и гороха с овсом при использовании на сидерат в паровом поле не имела существенных различий. Урожайность во второй срок посева имела существенную прибавку к посеву в первый срок и составила 21,4 ц/га гороха с овсом и 18,8 ц/га горчицы, что объясняется улучшением показателей плодородия почвы, повышением содержания гумуса и элементов питания, увеличением запасов продуктивной влаги, снижением объемной массы почвы и засоренности посевов.

В таблице 2 приведены данные по изменению агрохимических свойств почвы после двукратной запашки сидератов в паровом поле и использования биопрепаратов на льне.

Агротехнические приемы по запашке сидератов, внесению минеральных удобрений и биопрепаратов в посевах льна-долгунца в 2019 году способствовали снижению кислотности почвы, увеличению подвижных форм фосфора и обменного калия по сравнению с 2018 годом. 
Таблица 1. Эффективность использования горчицы белой и гороха с овсом на сидерат, 2018 г.

\begin{tabular}{|l|l|l|l|}
\multirow{2}{*}{ Варианты } & \multicolumn{2}{|l|}{ Урожайность, ц/га } & \multicolumn{2}{l|}{$\begin{array}{l}\text { Общая урожайность, } \\
\text { ц/га }\end{array}$} \\
\cline { 2 - 4 } & Посев 27 мая & Посев 22 июля & 185,4 \\
\hline Горох-овес & 82,0 & 103,4 & 194,8 \\
\hline Горчица & 88,0 & 106,8 & 10,1 \\
\hline НСР 05 & & & \\
\hline
\end{tabular}

Таблица 2. Влияние удобрений и биопрепаратов на агрохимические показатели почвы, 2019 г.

\begin{tabular}{l|l|l|l|l|}
\multirow{2}{*}{ Варианты } & \multirow{2}{*}{$\mathbf{p H}_{\text {сол }}$} & \multicolumn{2}{l|}{ Содержание, мг/100 г почвы } & \multirow{2}{*}{ Гумус,\% } \\
\cline { 3 - 5 } & & $\mathbf{P}_{2} \mathbf{O}_{5}$ & $\mathbf{K}_{2} \mathbf{O}$ & \\
\hline Яровые зерновые & 5,6 & 5,0 & 7,0 & 1,2 \\
\hline Фон - горох-овес на сидерат & 5,8 & 5,0 & 5,0 & 2,2 \\
\hline Фон - горчица белая на сидерат & 5,7 & 5,0 & 25,0 & 2,8 \\
\hline Горох-овес + биопрепараты & 6,0 & 5,0 & 25,0 & 2,9 \\
\hline Горчица белая + биопрепараты & 5,5 & 5,0 & 25,0 & 2,5 \\
\hline
\end{tabular}

Таблица 3. Влияние сидератов и биопрепаратов на урожайность льна-долгунца, 2019 г.

\begin{tabular}{|c|c|c|c|c|c|c|}
\hline \multirow[t]{2}{*}{ Варианты } & \multicolumn{2}{|c|}{ Урожайность, ц/га } & \multicolumn{2}{|c|}{ Прибавка к контролю, ц/га } & \multicolumn{2}{|c|}{$\begin{array}{l}\text { Прибавка } \\
\text { от биопрепаратов, ц/га }\end{array}$} \\
\hline & соломы & семян & соломы & семян & соломы & семян \\
\hline Яровые зерновые & 54,3 & 5,1 & - & - & - & - \\
\hline Горох-овес & 80,3 & 7,6 & 26,0 & 2,5 & - & - \\
\hline Горчица & 72,2 & 7,1 & 17,9 & 2,0 & - & - \\
\hline $\begin{array}{l}\text { Горох-овес+Трихозан+ } \\
\text { Витариз }\end{array}$ & 85,7 & 7,8 & 31,4 & 2,7 & 5,4 & 0,2 \\
\hline $\begin{array}{l}\text { Горчица+Трихозан+ } \\
\text { Витариз }\end{array}$ & 83,0 & 8,9 & 28,7 & 3,8 & 10,8 & 1,8 \\
\hline $\begin{array}{l}\text { Горох-овес +Трихозан+Витариз+ } \\
\text { Биоинсектицид }\end{array}$ & 104,0 & 15,5 & 49,7 & 10,4 & 23,7 & 7,9 \\
\hline $\begin{array}{l}\text { Горчица+Трихозан+ } \\
\text { Витариз+Биоинсекти-цид }\end{array}$ & 92,3 & 14,1 & 38,0 & 9,0 & 20,1 & 7,0 \\
\hline HCP05 & 15,6 & 2,8 & & & & \\
\hline
\end{tabular}

Таблица 4. Экономическая эффективность применения сидеральных предшественников и биопрепаратов при выращивании льна-долгунца

\begin{tabular}{|c|c|c|c|c|c|c|}
\hline \multirow{2}{*}{ Варианты } & \multicolumn{2}{|c|}{ Урожайность, ц/га } & \multirow{2}{*}{$\begin{array}{l}\text { Стоимость } \\
\text { урожая, руб/га }\end{array}$} & \multirow{2}{*}{$\begin{array}{l}\text { Стоимость } \\
\text { затрат, руб/га }\end{array}$} & \multirow{2}{*}{$\begin{array}{l}\text { учд, } \\
\text { руб/га }\end{array}$} & \multirow{2}{*}{$\begin{array}{l}\text { Рентабель- } \\
\text { ность,\% }\end{array}$} \\
\hline & семян & соломы & & & & \\
\hline Яровые зерновые & 5,1 & 54,3 & 170716 & 134519 & 37197 & 27,7 \\
\hline Горох-овес+Энерген & 7,6 & 80,3 & 252625 & 178199 & 74435 & 41,8 \\
\hline Горчица+Энерген & 7,1 & 72,2 & 227908 & 168357 & 59551 & 35,4 \\
\hline $\begin{array}{l}\text { Горох-овес+Трихозан+ } \\
\text { Витариз }\end{array}$ & 7,8 & 85,7 & 268720 & 183579 & 85141 & 46,4 \\
\hline $\begin{array}{l}\text { Горчица+Трихозан+ } \\
\text { Витариз }\end{array}$ & 8,9 & 83,0 & 264121 & 182091 & 82030 & 45,0 \\
\hline $\begin{array}{l}\text { Горох-овес +Трихозан+Витариз+ } \\
\text { Биоинсектицид }\end{array}$ & 15,5 & 104,0 & 343730 & 202701 & 141029 & 69,6 \\
\hline $\begin{array}{l}\text { Горчица+Трихозан+ } \\
\text { Витариз+Биоинсектицид }\end{array}$ & 14,1 & 92,3 & 306081 & 194318 & 111763 & 57,5 \\
\hline
\end{tabular}


Таблица 5. Устойчивость льна-долгунца к болезням при использовании биологических препаратов

\begin{tabular}{|l|l|l|}
\hline Вариант & $\begin{array}{l}\text { Всего больных } \\
\text { растений,\% }\end{array}$ & $\begin{array}{l}\text { В том числе фузариозная } \\
\text { гниль, \% }\end{array}$ \\
\hline Яровые зерновые & 28 & 28 \\
\hline Горох-овес & 28 & 28 \\
\hline Горчица белая & 18 & 18 \\
\hline Горох-овес + Трихозан + Витариз & 16 & 16 \\
\hline Горчица белая +Трихозан + Витариз & 14 & 14 \\
\hline Горох-овес +Трихозан + Витариз Ф Фитоверм & 14 & 14 \\
\hline Горчица белая +Трихозан + Витариз Ф Фитоверм & 10 & 10 \\
\hline
\end{tabular}

Таблица 6. Программа применения биопрепаратов на льне-долгунце

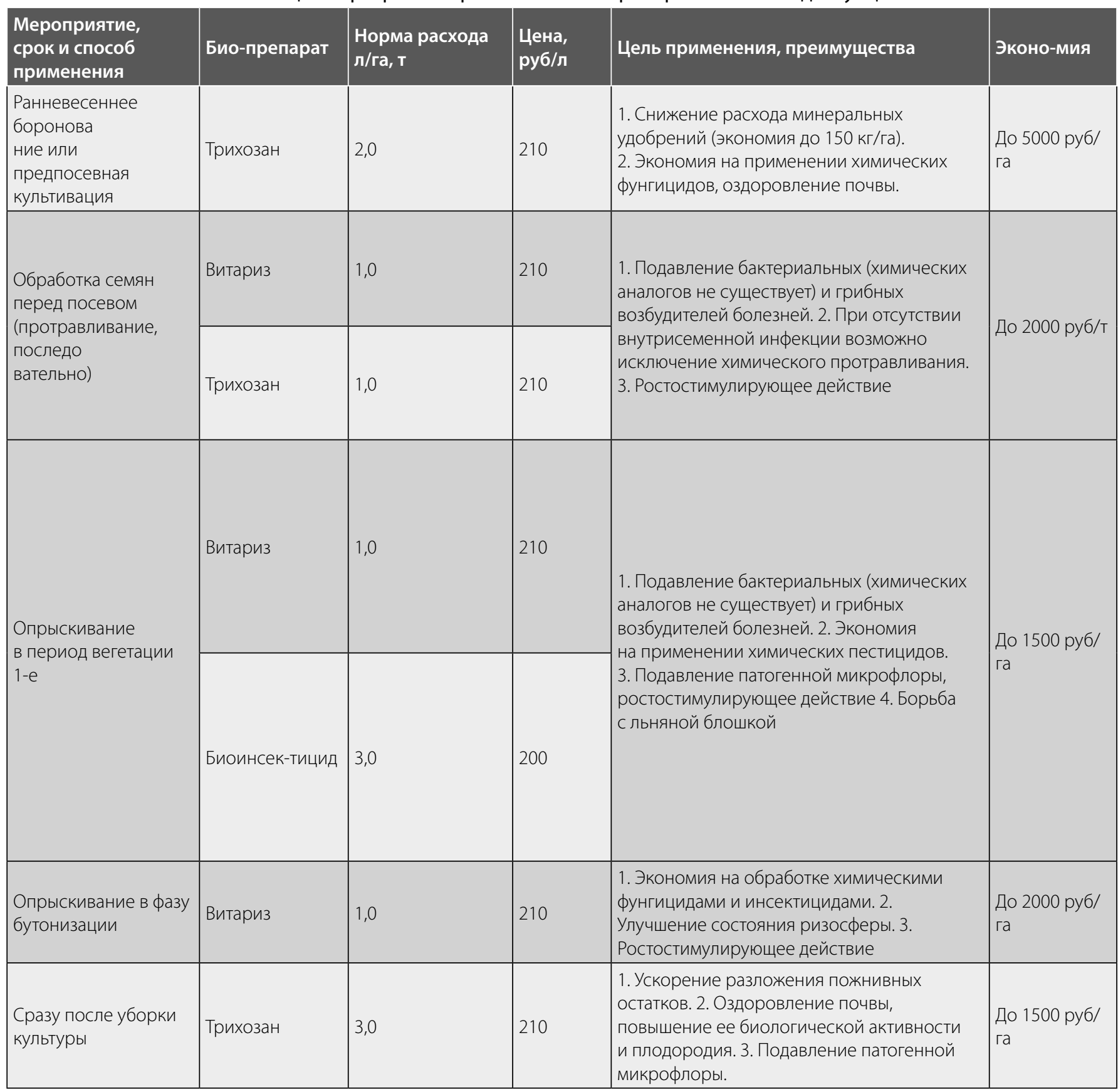


Применение биопрепаратов по фону горчицы увеличило содержание К2О на 20 мг/100 г почвы (табл. 2).

Биопрепараты характеризовались ростостимулирующим действием. Наибольшая прибавка урожайности семян и соломы получена при комплексном использовании биопрепаратов: Трихозан (обработка почвы)+Витариз и Трихозан (последовательное протравливание семян)+Витариз (обработка растений)+Биоинсектицид (обработка растений). Прибавка урожайности соломы составила 49,7 ц/га по фону горох-овес и 38 ц/га по фону горчица. Урожайность семян увеличилась соответственно на 10,4-9,0 ц/га, получены достоверные прибавки урожайности льнопродукции по обоим предшественникам. Биологические препараты, стимулируя рост и развитие растений, способствовали получению максимальной урожайности с единицы площади (табл. 3).

Дополнительные затраты на использование сидератов и биопрепаратов окупались дополнительным чистым доходом, уровень рентабельности увеличился по сравнению с размещением льна после яровых зерновых культур на 41,9\% по фону гороха с овсом и на 29,8\% по фону горчицы (табл. 4). Система применения биопрепаратов и сидератов при выращивании льна-долгунца направлена на реализацию сортового потенциала, экономию затрат и повышение экономической эффективности производства экологически чистой продукции.

Биопрепараты содержат природные компоненты на основе бактерий и грибов, подавляющих возбудителей болезней и вредителей льна в системе почва-растение. Устойчивость растений к фузариозу увеличилась при использовании биопрепаратов на 14\% по фону гороха с овсом и на 18\% по фону горчицы (табл. 5).

Общая экономия затрат от применения изучаемых биопрепаратов может достигать 10500 руб/га по сравнению с использованием агрохимикатов. На основании проведенных исследований рекомендуется система применения биопрепаратов на льне-долгунце. Система включает внесение Трихозана в почву осенью, после уборки предшествующей культуры с нормой расхода 3/га и весной, под ранневесеннее боронование или предпосевную культивацию с нормой расхода 2 л/га. Витариз в дозе 1 л/т и Трихозан-1 л/т следует применять для последовательного предпосевного протравливания семян. В период вегетации необходимо провести две обработки растений препаратом Витариз в дозе 1 л/га: первое опрыскивание проводится в фазу елочка, второе - в фазу бутонизации. Биоинсектицид рекомендуется для обработки посевов от льняной блошки в период появления вредителя (табл. 6).

\section{Выво $\triangle \mathrm{b}$}

Система применения биопрепаратов и сидератов при выращивании льна-долгунца направлена на реализацию сортового потенциала, экономию затрат и повышение экономической эффективности производства экологически чистой продукции.

Наибольшие прибавки урожайности соломы и семян получены при размещении льна после сидеральных предшественников и комплексном использовании биопрепаратов Трихозан, Витариз и Биоинсектицид. Реализован потенциал продуктивности сорта льна-долгунца Томский-17 на уровне 104,0 ц/ га соломы и 15,5 ц/га семян при использовании сидерального предшественника горох+овес и биопрепаратов. Уровень рентабельности составил $69,6 \%$ и увеличился на 41,9\% по сравнению с размещением льна после яровых зерновых культур. Использование сидеральных паров и биопрепаратов способствует увеличению плодородия почвы, продуктивности льна-долгунца, повышению экономической эффективности его возделывания.

\section{ЛИТЕРАТУРА}

1. Новиков А.Н., Лопачев Н. А., Баннова А. Н. Роль сидератов в воспроизводстве плодородия почв Верхневолжья // Вестник Орел ГАУ, № 4 (31) 2011 , с. 10-11.

2. Ивенин В.В., Ивенин А.В. Агротехнические особенности выращивания картофеля: Учебное пособие / Под ред. В.В. Ивенина.- СПб.: Изд-во Лань, 2015.- $336 \mathrm{C}$.

3. Ефремова Г. В. Изучение новых сортов льна-долгунца // Журн. Сибирский вестник сельскохозяйственной науки, 2015, № . 4, с. 26-31.

4. Порсев И.Н., Торопова Е. Ю., Купцевич Н. А., Саломатина К. С. Урожайность льна-долгунца и льна масличного в зависимости от сортового состава в условиях Центральной зоны Курганской области // Вестник Курганской ГСХА, № 1(17), 2016, с. 34-35.

5. Минеев В. Г. Практикум по агрохимии/В.Г. Минеев.-М.: Изд-во Московского университета.-2001.— c. 394-401.

( ) Ефремова Галина Вячеславовна ( efremova37@bk.ru ), Зотова Елена Юрьевна Журнал «Современная наука: актуальные проблемы теории и практики» 